\title{
North Spain (Burgos) WILD mammals ectoparasites
}

\author{
DOMÍNGUEZ G."
}

\section{Summary:}

Twenty-seven species of arthropods were collected from 105 wild mammals, six wolves Canis lupus (Linnaeus, 1758) included. A total of 87 animals $(82,8 \%)$ harboured some ectoparasites. Ticks were found in $60 \%$ of the samples, fleas in $51.4 \%$, chewing-lice in $3.8 \%$, and others (Mesostigmata and hippoboscids) in $3.8 \%$. Moreover, $42.5 \%$ were single infestation and $57.5 \%$ mixed. Some of the species were new records for a host in spanish country such as Trichodectes canis (De Géer, 1778), Ixodes trianguliceps (Birula, 1895), Ceratophyllus (Monopsyllus) S. sciurorum (Schrank, 1803) and Paraceras melis melis (Walker, 1856) on several mammals. Two species were new records for Spain: Chaetopsylla matina (Jordan, 1925) and Archaeopsylla erinacei erinacei (Bouché, 1835).

KEY WORDS : wild mammal, tick, flea, Chewing-lice, parasitic prevalence, Spain.

$\circlearrowleft$ ome arthropods play an important role in causing clinical disorders in man and animals, as acting as vectors of important diseases. However, few zoological studies, including hosts, distribution, ecology, and other factors on ectoparasites in wild animals, have been published.

In Spain revisions have been made by Gil Collado (1949, 1976); Sanchez Acedo et al. (1973); Beaucournu et al. (1973, 1990); Gilot et al. (1976); Martin (1977); Martinez et al. (1978); Encinas (1986); Estrada-Peña (1992) and Cordero del Campillo et al. (1994). Nevertheless, Estrada-Peña summarizes the present state of ticks knowledge and in the same way of other ectoparasites in Spain as discouraging and frustrating, keeping unstudied many Spanish areas and having an unfinished picture of the wild animal ectoparasites species. Other european authors carried out similar works, Beaucournu \& Launay (1990) and Aubert (1975) in France, Harris et al. (1978) and Hillyard (1996) in the UK, Travassos (1994) in Portugal, Manilla (1998) in

\footnotetext{
* Servicio Veterinario Oficial de Salud Pública, Centro de Salud, 09572-Soncillo, Burgos, Spain.

Correspondence: Gerardo Domínguez Peñafiel.

Tel.: 34947153181 - Fax: 34947153152.

E-mail: phetin@telefonica.net
}

Résumé : ECTOPARASITFS DE MAMMIFÈRES SELVATIQUES DU NORD DE L'ESPAGNE (Burgos)

Vingt-sept espèces d'arthropodes ont été recueillis sur 105 exemplaires de mammifères selvatiques, dont six loups Canis lupus (Linnaeus, 1758). Un total de 87 animaux (82,8\%) n'avaient aucun ectoparasite. Des tiques ont été trouvés dans $60 \%$ des cas, des puces dans $51,4 \%$, des mallophages dans $3,8 \%$ et d'autres (Acari, Mesostigmata et hippoboscides) dans 3,8\%. De même 42,5\% représentaient des infections simples et $57,5 \%$ mixtes. Quelques espèces sont des hôtes pour la première fois référencés en Espagne: Trichodectes canis (De Géer, 1778), |xodes trianguliceps (Birula, 1895), Ceratophyllus (Monopsyllus) S. sciurorum (Schrank, 1803) et Paraceras melis melis (Walker, 1856). Deux espèces sont des références nouvelles pour I'Espagne: Chaetopsylla matina Uordan, 1925) et Archaeopsylla erinacei erinacei (Bouché, 1835).

MOTS CLÉS : mammifère selvatique, tique, puce, mallophage, prévalence parasitaire, Espagne.

Italy, Schöffel et al. (1991) in Germany and others, some of them as the fox, Vulpes vulpes (Linnaeus, 1758), focused on specific areas, hosts or ectoparasites. This paper wishes to contribute to the knowledge of the distribution of vertebrate ectoparasites in a previously studied area, by extending the sampling zone, the number of investigated hosts (some of them only slightly studied as the wolf) and parasites and the study length. Moreover, the study zone is a biogeographical transitional area and has a great biological diversity.

\section{MATERIALS AND METHODS}

T The study zone averages $5,000 \mathrm{~km}^{2}$ includes a northern strip of Burgos province at $42^{\circ} 30^{\prime} \mathrm{N}$ $43^{\circ} 10^{\prime} \mathrm{N}$. Altitude ranging between $600-800 \mathrm{~m}$ on the plateau, and more than $1,100 \mathrm{~m}$ on the mountain foothills. In the northern sector, the winters are cold and humid and the summers are cool. Vegetation, under Atlantic influences, consists in oakwood and beechwood, with brushwood. The southern sector, submediterranean, shows similar winter, but hottest summers. Vegetation consists mainly in gall-oak groves 
and holm-oak wood, being brush scarce (Roman et al., 1996).

All the animals come from the study area and were collected between August 1997 and December 2000. Most of them, 96, were killed on roads, five were hunted, and four died on the Burgos Wildlife Recovery Centre. They were identified, being included into 17 species: wolf Canis lupus (Linnaeus, 1758) 6, fox Vulpes vulpes (Linnaeus, 1758) 26, stone marten Martes foina (Erxleben, 1777) 6, pine marten Martes martes (Linnaeus, 1758) 1, polecat Mustela putorius (Linnaeus, 1758) 7, weasel Mustela nivalis (Linnaeus, 1758) 2 , stout Mustela erminea (Linnaeus, 1758) 1, badger Meles meles (Linnaeus, 1758) 7, wild cat Felis silvestris (Schreber, 1775) 6, genet Genetta genetta (Linnaeus, 1758) 1, roe deer Capreolus capreolus (Linnaeus, 1758) 4, hedgehog Erinaceus europaeus (Linnaeus, 1758) 22, mole Talpa europaea (Linnaeus, 1758) 2, hare Lepus europaeus (Pallas, 1778) 4, red squirrel Sciurus vulgaris (Linnaeus, 1758) 7, fat dormouse Glis glis (Linnaeus, 1766) 2 and field vole Microtus arvalis (Linnaeus, 1758) 1.

After being identified, the animals were placed in plastic bags, containing an insecticide or ether. The ectoparasites recovered were placed in labelled vials containing $70 \%$ alcohol or were stored at $4^{\circ} \mathrm{C}$. Parasites were examined by means of a stereoscopic magnifying glass and a microscope. Except for the adult ticks and immature stages, fleas and lice were treated with $\mathrm{KOH} 10 \%$ solution and were mounted in Hoyer's or Berlese's mediums.
Parasites were identified by the keys of Hopkins et al. (1953), Smit (1957), Hutson (1984), Beaucournu \& Launay, (1990), Hillyard (1996) and Manilla (1998). Mesostigmata were only reported.

\section{RESULTS}

The study revealed (Table I) that 87/105 (82.8\%) of the animals were infested with ectoparasites.

The parasitic prevalence in each taxa was $60 \%$ for ticks, $51.4 \%$ for fleas, $3.8 \%$ for lice and $3.8 \%$ for others (Mesostigmata and hippoboscid).

Single parasitation was observed on 37 samples $(42.5 \%)$ and mixed parasitation was more frequent, being observed on 50 samples $(57.5 \%)$. Of the mixed, 30 samples (60 \%) of the specimens had two ectoparasites species, 14 samples (28\%) three and six samples (12\%) four. The host which showed more mixed infection was the hedgehog with 14 specimens (77.7\%) of parasited animals. Nevertheless, the wider variety of arthropods were observed on a badger with two ticks species and one flea and lice taxa.

The highest parasitic prevalence was observed on red squirrel, fox, wild cat, hedgehog, badger and wolf, being $85.7 \%, 84.6 \%, 83.3 \%, 81.8 \%, 100 \%$ and $100 \%$ respectively, although they were also the most frequent examined species. The badger and the wolf were the only hosts showing parasitation by some arthropods taxa steadily. Therefore, 63 animals (60\%) showed ticks, 54 animals (51.4\%) fleas, four animals (3.8\%) lice and

\begin{tabular}{|c|c|c|c|c|c|c|c|c|c|c|c|}
\hline \multirow{2}{*}{$\begin{array}{l}\text { Examined animals } \\
\text { hosts }\end{array}$} & \multirow[b]{2}{*}{$\mathrm{T}$} & \multicolumn{2}{|c|}{ Ticks } & \multicolumn{2}{|c|}{ Fleas } & \multicolumn{2}{|c|}{ Lice } & \multicolumn{2}{|c|}{ Others } & \multicolumn{2}{|c|}{$\begin{array}{l}\text { Parasitized } \\
\text { animals }\end{array}$} \\
\hline & & $\mathrm{n}$ & $\mathrm{P} \%$ & $\mathrm{n}$ & $\mathrm{P} \%$ & $\mathrm{n}$ & $\mathrm{P} \%$ & $\mathrm{n}$ & $\mathrm{P} \%$ & $\mathrm{n}$ & $\mathrm{P} \%$ \\
\hline Canis lupus & 6 & 3 & 50.0 & 4 & 66.6 & 1 & 16.6 & - & - & 6 & 100.0 \\
\hline Vulpes vulpes & 26 & 19 & 73.0 & 13 & 50.0 & - & - & - & - & 22 & 84.6 \\
\hline Felis silvestris & 6 & 4 & 66.6 & 4 & 66.6 & - & - & - & - & 5 & 83.3 \\
\hline Meles meles & 7 & 5 & 71.4 & 6 & 85.7 & 3 & 42.8 & - & - & 7 & 100.0 \\
\hline Martes foina & 6 & 2 & 33.3 & 4 & 66.6 & - & - & - & - & 4 & 66.6 \\
\hline Martes martes & 1 & - & - & 1 & 100.0 & - & - & - & - & 1 & 100.0 \\
\hline Mustela nivalis & 1 & - & - & - & - & - & - & - & - & - & - \\
\hline Mustela putorius & 7 & 1 & 14.2 & 1 & 14.2 & - & - & 1 & *14.2 & 3 & 42.8 \\
\hline Mustela erminea & 2 & 1 & 50.0 & - & - & - & - & - & - & 1 & 50.0 \\
\hline Genetta genetta & 1 & 1 & 100.0 & - & - & - & - & - & - & 1 & 100.0 \\
\hline Capreolus capreolus & 4 & 4 & 100.0 & - & - & - & - & 1 & $* 25.0$ & 4 & 100.0 \\
\hline Lepus europaeus & 4 & 4 & 100.0 & - & - & - & - & - & - & 4 & 100.0 \\
\hline Sciurus vulgaris & 7 & 4 & 57.1 & 5 & 71.4 & - & - & - & - & 6 & 85.7 \\
\hline Glis glis & 2 & - & - & 2 & 100.0 & - & - & - & - & 2 & 100.0 \\
\hline Microtus arvalis & 1 & - & - & - & - & - & - & 1 & "100.0 & 1 & 100.0 \\
\hline Talpa europaea & 2 & - & - & 2 & 100.0 & - & - & 1 & $* 50.0$ & 2 & 100.0 \\
\hline Erinaceus europaeus & 22 & 15 & 68.0 & 12 & 54.5 & - & - & - & - & 18 & 81.8 \\
\hline Total hosts: & 105 & 63 & 60.0 & 54 & 51.4 & 4 & 3.8 & 4 & 3.8 & 87 & 82.8 \\
\hline
\end{tabular}

T: Total hosts. n: Number of parasited animals. P \%: Parasitic prevalence. "Mesostigmata, ${ }^{* *} M$. ovinus.

Table I. - Ectoparasites distribution among the different host species. 
four animals (3.8\%) others such as Mesostigmata and Melophagus ovinus (Linnaeus, 1761).

Ticks: we found 593 ticks included on 10 species (Table II). The hedgehog, fox and badger showed the greater ixodidae variety, six and four species each other, respectively. Two or more ticks species were observed on 24 specimens ( $40 \%$ ) of the mixed infestation. The most frequent association was Ixodes ricinus (Linnaeus, 1746) and Ixodes hexagonus (Leach, 1815) on eight samples, followed by Haemaphysalis punctata (Canestrini \& Fanzago, 1877) and Dermacentor reticulatus (Fabricius, 1794).

I. ricimus was the most prevalent being found on 30 samples from 10 hosts. H. punctata was found on 16 samples from seven hosts and $I$. hexagonus on 24 samples from seven hosts, were others usual ticks species. D. reticulatus was mainly a fox and wolf ectoparasite, being observed on $36.8 \%$ and $33 \%$ of the parasited animals, meanwhile others ticks were scarcely detected in the zone. The roe deer showed high parasitic intensity, 47 ticks/animal.

Fleas: we found 348 fleas belonging to 14 species (Table III). Fox, wild cat, and stone marten showed the greatest variety of fleas, four species each one. Paraceras melis melis (Walker, 1856) had the wider host range, four species, meanwhile Pulex irritans (Linnaeus, 1758) was the most prevalent since it appeared on 13 samples, but only on three hosts, although was high, such on the fox, $61,5 \%$ and the wolf, $100 \%$. The fox was the only Ctenocephalides canis (Curtis, 1825 ) host (53.8\%). Ceratophyllus (Monopsyllus) sciurorum sciurorum (Schrank, 1803) was observed on four hosts, two of them primary hosts and two accidental. Chaetopsylla trichosa (Kohaut, 1903) was found on $33.3 \%$ of the badgers, being rare in other carnivora. Archaeopsylla erinacei erinacei (Bouchè, 1835) was more prevalent than subspecies maura, $66.6 \%$ and $16.6 \%$ respectively. The first showed a notorious parasitic intensity (13.8 fleas/host) and was the most common flea species in the study.

Two or more fleas species were observed on 13 samples, $26 \%$ mixed infestations and the usual association was C. canis and P. irritans, four samples. Ctenocephalides felis felis (Bouché, 1835) showed the higher parasitic intensity, 36 fleas/stone marten. Other fleas were scarcely collected, many of them in accidental hosts.

Chewing-lice: we also found 1,550 lice belonging to two species: Trichodectes melis (Fabricius, 1805), Trichodectes canis (De Géer, 1778). They were observed on the badger and on the wolf showing a parasitic intensity of 300 and 650 lice per animal, respectively. Others: the hippoboscid Melophagus ovinus was incidentally collected on the roe deer, as well as Mesostigmata (unidentified) on two micromammals and on the polecat.

\section{DISCUSSION}

\author{
TICKS
}

2 oe deer is in our area a suitable maintenance host of Ixodes ricinus, showed high intensity and - parasitic prevalence, as well as several specimens. This tick was present in all study area, increasingly in the northern sector (600-1,200 $\mathrm{mm}$ rainfalls), and in a similar way as in European countries (Gilot et al., 1994; Aubert, 1975), and meanwhile is scarcely in southern sector, as in different submediterranean regions in Spain (Encinas, 1986; Estrada-Peña et al., 1992).

Ixodes hexagonus was a new record in the study area, being always associated to the hedgehog, as well as to little and middle carnivora and his burrows (Travassos, 1994). The parasitic prevalence found in foxes was lower than reported by Aubert (1975) in France, but higher than mentioned by Encinas (1986) in Salamanca, where he reported the change of genus $R \mathrm{hi}$ picephalus Koch in the warm period for genus Ixodes Latreille in the cool period. We found autumn-winter asociation between $I$. hexagonus and D. reticulatus and the replacement of the last by $I$. ricimus along spring. Ixodes canisuga (Johnston, 1849) shows preference for other environments, as previously reported on fox in the Spanish mediterranean zone (Encinas, 1986; Estrada-Peña et al., 1992), but it was a surprising new record on the badger, despite being a frequent species in Europe in this host (Hillyard, 1996; Aubert, 1975).

Ixodes ventalloi (Gil Collado, 1936) is a tick of the subhumid areas of Spain, despite Encinas (1986) does not find it in Salamanca. We collected it restricted to the hedgehog, in a submediterranean environment.

Ixodes trianguliceps (Birula, 1895) is found scarcely in Spain, only in the Eurosiberian zone (Gilot et al., 1976; Estrada-Peña, 1995). A nymph was collected on a squirrel, host not previously recorded in Spain, but usual in other european countries (Hillyard, 1996).

Haemaphysalis punctata colonizes mediterranean areas, but humid zones in the northern Burgos were more suitable (Dominguez, 1999). Adults were found in the hosts from the end of the summer until spring, together with $I$. ricinus, especially in non carnivora mammals (Estrada-Peña, 1992).

Dermacentor reticulatus occurs in Cantabric bushy environments (Cordero et al., 1994), where it was the most active and prevalent species in the Burgos humid zone during the cool months (Dominguez, 1999). It showed affinity for the Canidae (wolf and fox) in our area, but other reports in Spain (Estrada-Peña et al., 1992) pointed out that it was not collected in foxes, being considered Centraleuropean species (Encinas, 1986). In 


\begin{tabular}{|c|c|c|c|c|c|c|c|c|c|c|c|c|c|c|c|c|c|c|c|c|c|c|c|c|c|c|c|c|c|}
\hline \multirow[b]{2}{*}{ Host $(\mathrm{T})$} & \multirow[b]{2}{*}{$\mathrm{N}$} & \multicolumn{3}{|c|}{$\begin{array}{l}\text { Ixodes } \\
\text { ricinus }\end{array}$} & \multicolumn{3}{|c|}{$\begin{array}{c}\text { Ixodes } \\
\text { bexagonus }\end{array}$} & \multicolumn{3}{|c|}{$\begin{array}{c}\text { Ixodes } \\
\text { canisuga }\end{array}$} & \multicolumn{3}{|c|}{$\begin{array}{c}\text { Ixodes } \\
\text { ventalloi }\end{array}$} & \multicolumn{2}{|c|}{$\begin{array}{c}\text { Ixodes } \\
\text { trianguliceps } \\
\end{array}$} & \multicolumn{3}{|c|}{$\begin{array}{c}\text { Haemaphysalis } \\
\text { punctata }\end{array}$} & \multicolumn{3}{|c|}{$\begin{array}{c}\text { Dermacentor } \\
\text { reticulatus }\end{array}$} & \multicolumn{2}{|c|}{$\begin{array}{l}\text { Dermacentor } \\
\text { marginatus }\end{array}$} & \multicolumn{3}{|c|}{$\begin{array}{c}\text { Rhipicephalus } \\
\text { turanicus } \\
\end{array}$} & \multicolumn{3}{|c|}{$\begin{array}{c}\text { Rhipicephalus } \\
\text { pusillus }\end{array}$} \\
\hline & & I & A & $\mathrm{n}$ & I & A & $\mathrm{n}$ & I & A & $\mathrm{n}$ & I & A & $\mathrm{n}$ & I $t$ & $\mathrm{~A} n$ & I & A & $\mathrm{n}$ & I & $\mathrm{A}$ & $\mathrm{n}$ & I A & $\mathrm{n}$ & I & A & $\mathrm{n}$ & I & $\mathrm{A}$ & $\mathrm{n}$ \\
\hline Canis lupus (6) & 3 & & 6 & 1 & & & & & & & & & & & & & & & & 1 & 1 & & & & & & & 18 & 1 \\
\hline Vulpes vulpes (26) & 19 & 12 & 11 & 9 & 72 & 13 & 8 & & & & & & & & & 3 & & 1 & & 55 & 7 & & & & & & & & \\
\hline Felis silvestris (6) & 4 & & 1 & 1 & 8 & & 2 & & & & & & & & & 2 & & 2 & & & & & & & & & & & \\
\hline Meles meles (7) & 5 & & 1 & 1 & 5 & & 2 & 1 & 1 & 2 & & & & & & 1 & & 1 & & & & & & & & & & & \\
\hline Mustela foina (6) & 2 & 1 & 1 & 2 & 2 & 2 & 2 & & & & & & & & & 1 & & 1 & & & & & & & & & & & \\
\hline Mustela putorius (7) & 1 & & & & 1 & & 1 & & & & & & & & & & & & & & & & & & & & & & \\
\hline Mustela erminea (2) & 1 & & & & 1 & & 1 & & & & & & & & & & & & & & & & & & & & & & \\
\hline Genetta genetta (1) & 1 & 26 & & 1 & & & & & & & & & & & & & & & & & & & & & & & & & \\
\hline Capreolus capreo (4) & 4 & 68 & 120 & 4 & & & & & & & & & & & & & & & & & & & & & & & & & \\
\hline Lepus europaeus (4) & 4 & 9 & 1 & 2 & & & & & & & & & & & & 24 & 2 & 3 & & & & & & & & & & & \\
\hline Sciurus vulgaris (7) & 4 & 14 & & 3 & & & & & & & & & & 1 & 1 & 2 & & 2 & & & & 1 & 1 & & & & & & \\
\hline Erinaceus europ (22) & 15 & 52 & 4 & 6 & 17 & 5 & 8 & & & & & 3 & 2 & & & 9 & 4 & 6 & & & & 4 & 2 & & 7 & 1 & & & \\
\hline Total hosts (98) & 103 & 182 & 145 & 30 & 106 & 20 & 24 & 1 & 1 & 2 & & 3 & 2 & 1 & 1 & 42 & 6 & 16 & & 56 & 8 & 5 & 3 & & 7 & 1 & & 18 & 1 \\
\hline
\end{tabular}

(T): Total hosts. N: Number of parasited hosts (any tick). n: Number of parasited hosts (each tick species). I: Immature. A: Adult (each tick species).

Table II. - Ticks distribution among the different host species.

\begin{tabular}{|c|c|c|c|c|c|c|c|c|c|c|c|c|c|c|c|c|c|c|c|c|c|c|c|c|c|c|c|c|c|}
\hline \multirow[b]{2}{*}{ Host $(\mathrm{T})$} & \multirow[b]{2}{*}{$\mathrm{N}$} & \multicolumn{2}{|c|}{$\begin{array}{l}\text { Pa.m. } \\
\text { melis }\end{array}$} & \multicolumn{2}{|c|}{$\begin{array}{c}P u . \\
\text { irritans } \\
\end{array}$} & \multicolumn{2}{|c|}{$\begin{array}{l}\text { Ct. } f \text {. } \\
\text { felis }\end{array}$} & \multicolumn{2}{|c|}{ Ct. canis } & \multicolumn{2}{|c|}{$\begin{array}{l}\text { Ce. (M.) s. } \\
\text { sciurorum }\end{array}$} & \multicolumn{2}{|c|}{$\begin{array}{c}\text { Ch. } \\
\text { trichosa }\end{array}$} & \multicolumn{2}{|c|}{$\begin{array}{c}C h \\
\text { matina }\end{array}$} & \multicolumn{2}{|c|}{$\begin{array}{c}\text { Ar.e. } \\
\text { erinacei }\end{array}$} & \multicolumn{2}{|c|}{$\begin{array}{l}\text { Ar.e. } \\
\text { maura }\end{array}$} & \multicolumn{2}{|c|}{$\begin{array}{c}\text { No. } \\
\text { fasciatus }\end{array}$} & \multicolumn{2}{|c|}{$\begin{array}{l}\text { Ctenophthal } \\
\text { mus spp. }\end{array}$} & \multicolumn{2}{|c|}{$\begin{array}{c}\text { Sp. } \\
\text { cuniculi }\end{array}$} & \multicolumn{2}{|c|}{$\begin{array}{c}\text { Pe.S. } \\
\text { spectabilis }\end{array}$} & \multicolumn{2}{|c|}{$\begin{array}{l}\text { Pa. } \\
\text { minor }\end{array}$} \\
\hline & & A & $\mathrm{n}$ & A & $\mathrm{n}$ & A & $\mathrm{n}$ & A & $\mathrm{n}$ & A & $\mathrm{n}$ & A & $\mathrm{n}$ & A & $\mathrm{n}$ & A & $\mathrm{n}$ & A & $\mathrm{n}$ & A & $\mathrm{n}$ & A & $\mathrm{n}$ & A & $\mathrm{n}$ & A & $\mathrm{n}$ & A & $\mathrm{n}$ \\
\hline Canis lupus (6) & 4 & 1 & 1 & 7 & 4 & & & & & & & & & & & & & & & & & & & & & & & & \\
\hline Vulpes vulpes (26) & 13 & 4 & 2 & 22 & 8 & 4 & 2 & 27 & 7 & & & 1 & 1 & & & & & & & & & & & & & & & & \\
\hline Felis silvestris (6) & 4 & & & & & 1 & 1 & & & 1 & 1 & & & & & & & & & & & 1 & 1 & 6 & 1 & 1 & 1 & & \\
\hline Meles meles (7) & 6 & 6 & 5 & & & & & & & & & 4 & 2 & & & & & & & & & & & & & & & & \\
\hline Mustela foina (6) & 5 & 3 & 1 & & & 36 & 1 & & & & & 1 & 1 & 2 & 1 & & & & & 1 & 1 & & & & & & & & \\
\hline Martes martes (1) & 1 & & & & & & & & & 1 & 1 & & & & & & & & & & & & & & & & & & \\
\hline Mustela putorius (7) & 1 & 1 & 1 & & & & & & & & & & & & & & & & & & & & & & & & & & \\
\hline Sciurus vulgaris (7) & 5 & & & & & & & & & 29 & 5 & & & & & & & & & & & & & & & & & & \\
\hline Glis glis (2) & 2 & & & & & & & & & 2 & 2 & & & & & & & & & & & & & & & & & & \\
\hline Microtus arvalis (2) & 2 & & & & & & & & & & & & & & & & & & & & & 1 & 1 & & & & & 3 & 1 \\
\hline Erinaceus europ. (22) & 12 & & & 2 & 1 & & & & & & & & & & & 111 & 8 & 2 & 2 & & & 1 & 1 & & & & & & \\
\hline Total host (93) & 54 & 15 & 10 & 31 & 13 & 41 & 4 & 27 & 7 & 33 & 9 & 6 & 4 & 2 & 1 & 111 & 8 & 2 & 2 & 1 & 1 & 3 & 3 & 6 & 1 & 1 & 1 & 3 & 1 \\
\hline
\end{tabular}

(T): Total hosts. N: Number of parasited hosts (any flea). n: Number of parasited hosts (each flea species). A: Adult (each flea species).

Table III. - Flea distribution among the different host species. 
the UK, Harris \& Thompson (1978) has neither recorded this species on the carnivora.

Dermacentor marginatus (Sulzer, 1776) is more or less a xerophilic species, despite bearing rainfalls ranges until $1,000 \mathrm{~mm}$ in Portugal (Travassos, 1994), as in our study area. We recovered two nymphs on hedgehogs and on red squirrel during the summer, when the immatures were active, according with Estrada-Peña et al. (1992).

Rhipicephalus turanicus (Pomeranzev, 1940) is rare in our humid areas (Travassos, 1994), and the hedgehog is a frequent host for immature stages in the nonAfrican environments (Walker et al., 2000) and new record in our province.

Rhipicephalus pusillus (Gil Collado, 1938) parasited the rabbit, Oryctolagus cuniculus (Linnaeus, 1758) and his predators, the fox, wolf and others (Cordero et al., 1994). A wolf record from the South of the province was included in order to compare South and North populations that on our findings basis, were endophilic and exophilic species (I. ricinus and D. reticulatus), respectively in each area.

\section{FLEAS}

Paraceras m. melis was collected on carnivora such as badger, his main host (Gil Collado, 1949; Sanchez et al. 1973), stone marten, polecat and wolf, due to the use of badgers burrows or due to predation by other carnivora like the wolf. Similar to our observations, some European reports point to the fox as a suitable host (Smit, 1957; Beaucournu \& Launay, 1990).

Pulex irritans has the wider range hosts, however, many authors (Smit, 1957; Beaucournu \& Launay, 1990) describe this species as characteristic of dog and other carnivora, some confirmed in our study, being the most prevalent flea on the fox and on the wolf (only slightly studied previously). Gracia et al. (2000) reported high prevalence in kennels and among people working on them, both being suitable hosts (Martinez et al., 1978; Cordero et al., 1994). This species was found in all the area, being more frequently at the end of the summer (Beaucournu \& Launay, 1990).

Ctenocephalides $f$. felis is widely distributed all the year round in domestic and synanthropic carnivora causing human diseases and nuisances (Beaucournu \& Launay, 1990). Nevertheless, we only observed intensive parasitation on a stone marten, and with lower frequencies in fox or wild cat, source of infestation for other animals and man.

Ctenocephalides canis is the main dog and fox flea (Smit, 1957). We considered the last one as the only host in the area. Our results agree with those described by Beaucournu \& Launay (1990), suggesting that in its distribution areas this flea is not as usual as expected among some vertebrates.
Ceratophyllus (M.) s. sciurorum occurs in northern Iberian Peninsula (Beaucournu \& Launay, 1990), as well as his main hosts, red squirrel and fat dormouse. Our findings bear out the usual presence of the parasite in both hosts. Meanwhile the recovering in wild cat and pine marten, recorded by Smit (1957) and Beaucournu \& Launay (1990), might be ascribed to the predation of this carnivora.

Chaetopsylla trichosa was reported for the first time in Spain on the badger by Gil Collado (1949) as C. trichosa hispanica. We found the flea on stone marten and fox, as secondary hosts. Badger is the main host, as we previously observed in South Burgos (unpublished data). Nevertheless, we agree with Beaucournu \& Launay (1990) that this species is not abundant on the hosts.

Chaetopsylla matina (Jordan, 1925) was found on the stone marten, in the Bocos Port at $900 \mathrm{~m}$ height. As far as we know, it is a new record for Spain, and Beaucournu \& Launay (1990) report this species in the Pyrenees as a specimen of discontinuous distribution, unfrequent and of unknown ecology.

Archaeopsylla erinacei has two subspecies in the Mediterranean area, but only one, Archaeopsylla erinacei maura (Jordan \& Rothschild,1912), in the Iberian Peninsula (Smit, 1957; Gil Collado, 1976). We reported for the first time the subspecies erinacei in Spain, following the keys of Beaucournu \& Launay (1990). This subspecies was the more frequent, both as prevalence and as abundance, than subspecies maura, which was only found in two southern places. We must emphasize the notorious intensity of infestation by subspecies erinacei, as reported in the UK by Smit (1957). Nosopsyllus fasciatus (Bosc D'Antic, 1801) was collected on a stone marten, probably being infected after predation of a wild or domestic rodent (Rattus spp.).

Others fleas were scarcely found, such as genus Ctenophthalmus Kolenati a micromammals parasite. We only collected one specimen on a usual host, the mole (Beaucournu \& Launay, 1990). Other findings were in accidental hosts, one on a hedgehog and one on a wild cat, as predators.

Spilopsyllus cuniculi (Dale, 1878) distribution in Spain is closely related to that of its preferred host, the rabbit Oryctolagus cuniculus (Linnaeus, 1758). It was found on an accidental host, the wild cat, from the southern limit of the study area, where there are rabbit populations. Beaucournu \& Launay (1990) also reported the role of some carnivora as accidental hosts, as well as described for Peromyscopsylla spectabilis spectabilis (Rothschild, 1912), that we found on a wild cat. Palaeopsylla minor (Dale, 1876) is present in the Spanish and European grasslands (Smit, 1957; Cordero et al., 1994), and on his inhabitants, the moles, where we recovered the parasites. 


\section{MallophaGa}

Respect to the Mallophaga, we reported Trichodectes melis for the first time in the Burgos province on half $(42,8 \%)$ of the investigated badgers. Two specimens showed a high infestation intensity, focused on head and neck. Trichodectes canis, found in a young wolf and previously cited on dogs (Martin, 1977), is a new record in the Iberian Peninsula, showing an intensive parasitation and similar body distribution than badger.

\section{ACKNOWLEDGEMENTS}

Thes The author wishes to thank Prof. Antonio Encinas Grandes and Olga Alarcia Alejos for technical assistance and Dr. Alberto Espí Felgueroso and Eloy Fernandez de Montoya for their help in the preparation of the manuscript. This work was awarded with the 2003 Real Academia de Medicina y Cirugia de Valladolid prize.

\section{REFERENCES}

Aubert M.F.A. Contribution a l'étude du parasitisme du renard (Vulpes vulpes) par les Ixodidae (Acarina) dans le NordEst de la France. Acarologia, 1975, XVII (3), 452-479.

Beaucournu J.C., Gilot B. \& Vericad J.R. Contribution à l'étude des Siphonaptères du Sud-Est de la Péninsule Iberique. Eos, 1973, 49, 49-78.

Beaucournu J.C. \& Launay H. Les puces de France et du bassin méditerranéen occidental. Faune de France 76, Paris, 1990.

Cordero del Campillo M., Castañon L., \& Reguera A. Indicecatalogo de zooparásitos Ibéricos. $2^{\mathrm{a}}$ ed. Secretariado de Publicaciones, León, 1994.

Domínguez G. Las garrapatas (Ixodidae) en el NW. de Burgos. Aspectos de su ecología e interés sanitario. Medicina Veterinaria 1999, 16 (11), 525-535.

Encinas A. Ticks of the province of Salamanca (Central/NW Spain). Annales de Parasitologie Humaine et Comparée, 1986, 61, 95-107.

Estrada-Peña A., Osacar J.J., Gortazar C., Calvete C. \& LUCIENTES $\mathrm{J}$. An account of the ticks of the northeastern of Spain. Annales de Parasitologie Humaine et Comparée, 1992, 67, 42-49.

Estrada-Peña A., Oteo J.A., Estrada-Peña R., Gortazar C., Osacar J.J., Moreno J.A. \& Castella J. Borrelia burgdorferi sensu lato in ticks (Acari: Ixodidae) from two different foci in Spain. Experimental and Applied Acarology, 1995, 19, 173-180.

Estrada-Peña A. Catálogo geográfico de las garrapatas en la Península Ibérica. Mallinckrodt Veterinary, Madrid, 1995.

Gil Collado J. Pulgas españolas parásitas de roedores, Revista Iberica de Parasitologia, 1949, IX, 213-258.

Gil Collado J. \& Rivas L.I. Nuevas citas de sifonápteros parásitos de mamíferos en España. Acta Vertebrata, 1976, 3 (1), 79-88
Gilot B., Pautou G., Gosalbez J. \& Moncada E. Contribution à l'étude des Ixodidae (Acarina, Ixodoidea) des Monts Cantabriques (Espagne). Annales de Parasitologie Humaine et Compareé, 1976, 51 (2), 241-254.

Gilot B., Bonnefille M., Degeilh B., Beaucournu J.C., Pichot J. \& Guiguen C. The colonization of forested areas by Ixodes ricimus in France: use of the roedeer, Capreolus capreolus as a biological marker. Parasite, 1994, 1, 81-85.

Gracia M.J., Lucientes J.A., Castillo M.A., La Torre E., Zarate J. \& Arbea I. Pulex irritans infestation in dogs. Veterinary Record, 2000, Dec, 23-30.

Harris S. \& Thompson G.B. Populations of the ticks Ixodes (Pholeoixodes) hexagonus and Ixodes (Pholeoixodes) canisuga infesting suburban foxes (Vulpes vulpes). Journal of Zoology of London, 1978, 186, 83-93.

Hillyard P.D. Ticks of North-West Europe. British Fauna, $n^{\circ}$ 52. Barnes \& Crothers, London, 1996.

Hopkins G.H.E. \& Rothschild M. An illustrated Catalogue of the Rothschild collection of fleas (Siphonaptera) in the British Museum (Natural History). Vol. I, Tungidae and Pulicidae. British Museum, London, 1953.

Hutson A.M. Keds, Flat-Flies and Bat-flies. Handbooks for the identification of British insects. Vol. 10, Part 7. Royal of Entomological Society, London, 1984.

Manilla G. Fauna d'Italia Acari Ixodida. Ed. Calderini, Bologna, 1998

MarTín M.P. Estudio de Trichodectidae (Mallophaga: Insecta) parásitos de mamíferos en España. Revista Iberica de Parasitologia 1977, 37, 1-25.

Martínez F., Hernández S., Calero R. \& Moreno T. Contribución al conocimiento de los parásitos del zorro (Vulpes vulpes). Revista Iberica de Parasitologia, 1978, 38, 208-211.

Roman J., Roman L., Ansola L.M., Palma C. \& Ventosa R. Atlas de las aves nidificantes de la provincia de Burgos. Ed. CACO, Burgos, 1996.

SANChez C. \& VericaD J.R. Ectoparásitos de mamíferos y aves montaraces del alto Aragón. Revista Iberica de Parasitologia, 1973, 33, 29-38.

Schöffel I., Schein E., Wittstadt U. \& Hentsche J. Zur Parasitenfauna des Rotfuchses in Berlin (West). Berliner und Münchener Tierärztliche, 1991, 104, 153-157.

SMIT F.G.A.M. Siphonaptera. Handbooks for the identification of British insects, Vol. 1, Part. 16. Royal of Entomological Society, London, 1957.

Travassos Santos Dias J.A. As carracas (Acarina-Ixodoidea) da Península Ibérica. Ministerio do Planeamento e Admon. Do Territorio, Lisboa, 1994.

Walker J.B., Keirans J.E. \& Horak I.G. The genus Rhipicephalus (Acari: Ixodidae). A guide to the brown ticks of the world, $1^{\text {st }}$ ed., New York, 2000.

Reçu le 12 juin 2003 Accepté le $1^{\text {er }}$ avril 2004 